\title{
Methods Employed in Cytofluorometric Assessment of Eryptosis, the Suicidal Erythrocyte Death
}

\author{
Mohamed Jemaàa,b Myriam Fezai ${ }^{a}$ Rosi Bissinger ${ }^{a}$ Florian Lang ${ }^{c, d}$ \\ aDepartment of Internal Medicine III, University of Tuebingen, Germany; ${ }^{b}$ Department of Laboratory \\ Medicine, Translational Cancer Research, Lund University, Lund, Sweden; 'Department of Molecular \\ Medicine II, Heinrich Heine University Duesseldorf, dDepartment of Physiology I, University of \\ Tuebingen, Germany
}

\section{Key Words}

RBC - Calcium - Cell volume - Cell membrane scrambling • ROS • Ceramide - Glutathion • Caspases • Kinases $•$ NSC-95397 • Bi-2536 • Fascaplycin • Lopinavir • Terfenadine • Fucoxanthin

\begin{abstract}
Suicidal erythrocyte death or eryptosis contributes to or even accounts for anemia in a wide variety of clinical conditions, such as iron deficiency, dehydration, hyperphosphatemia, vitamin D excess, chronic kidney disease (CKD), hemolytic-uremic syndrome, diabetes, hepatic failure, malignancy, arteriitis, sepsis, fever, malaria, sickle-cell disease, beta-thalassemia, $\mathrm{Hb}-\mathrm{C}$ and G6PD-deficiency, Wilsons disease, as well as advanced age. Moreover, eryptosis is triggered by a myriad of xenobiotics and endogenous substances including cytotoxic drugs and uremic toxins. Eryptosis is characterized by cell membrane scrambling with phosphatidylserine exposure to the erythrocyte surface. Triggers of eryptosis include oxidative stress, hyperosmotic shock, and energy depletion. Signalling involved in the regulation of eryptosis includes $\mathrm{Ca}^{2+}$ entry, ceramide, caspases, calpain, p38 kinase, protein kinase $C$, Janus-activated kinase 3 , casein kinase $1 \alpha$, cyclin-dependent kinase 4, AMP-activated kinase, p21-activated kinase 2, cGMPdependent protein kinase, mitogen- and stress-activated kinase MSK1/2, and ill-defined tyrosine kinases. Inhibitors of eryptosis may prevent anaemia in clinical conditions associated with enhanced eryptosis and stimulators of eryptosis may favourably influence the clinical course of malaria. Additional experimentation is required to uncover further clinical conditions with enhanced eryptosis, as well as further signalling pathways, further stimulators, and further inhibitors of eryptosis. Thus, a detailed description of the methods employed in the analysis of eryptosis may help those, who enter this exciting research area. The present synopsis describes the experimental procedures required for the analysis of phosphatidylserine exposure at the cell surface with annexin- $V$, cell volume with forward scatter, cytosolic $\mathrm{Ca}^{2+}$ activity $\left(\left[\mathrm{Ca}^{2+}\right]_{i}\right)$ with Fluo3, oxidative stress with 2',7'-dichlorodihydrofluorescein diacetate (DCFDA), glutathione (GSH) with mercury orange 1(4-chloromercuryphenyl-azo-2-naphthol), lipid peroxidation with BODIPY 581/591 C11 fluorescence, and ceramide abundance with specific antibodies. The contribution of kinases and caspases is defined with the use of the respective inhibitors.

M. Jemaà and F. Lang share senior co-authorship.

Dr. Mohamed Jemaà, and Prof. Dr. Florian Lang

Department of Physiology I, University of Tuebingen, Gmelinstr. 5, D-72076 Tuebingen, (Germany)

E-Mail jemaamohamed@gmail.com/florian.lang@uni-tuebingen.de
\end{abstract}




\section{Cellular Physiology Cell Physiol Biochem 2017;43:431-444 \begin{tabular}{l|l|l} 
DOI: 10.1159/000480469 & $\begin{array}{l}\text { (c) } 2017 \text { The Author(s). Published by S. Karger AG, Basel } \\
\text { www.karger.com/cpb }\end{array}$
\end{tabular} \\ Jemaà et al.: Methods in the Analysis of Eryptosis}

It is hoped that the present detailed description of materials and methods required for the analysis of eryptosis encourages further scientists to enter this highly relevant research area.

(C) 2017 The Author(s)

Published by S. Karger AG, Basel

\section{Introduction}

Suicidal death of mature red blood cells (RBCs) or erythrocytes is commonly named eryptosis. Similar to apoptosis of nucleated cells, eryptosis typically leads to cell shrinkage, cell membrane blebbing and cell membrane scrambling with phosphatidylserine translocation to the erythrocyte surface [1-7]. The signalling triggering eryptosis includes in most cases the activation of $\mathrm{Ca}^{2+}$ permeable channels with increase of cytosolic $\mathrm{Ca}^{2+}$ activity $[8,9]$. However, several further mechanisms may be involved, such as oxidative stress, energy depletion, excessive cell shrinkage, calpain, caspases, ceramide, eicosanoids, and diverse kinases [8,9].

Eryptosis is a common clinical problem, as it is triggered by a myriad of xenobiotics as well as endogenous substances [1-3, 10-68] and accelerated eryptosis is observed in a variety of clinical disorders including iron deficiency [1-3], dehydration [69], hyper-cholesterolemia and enhanced oxysterol levels [70, 71], hyperphosphatemia [72], vitamin D excess [36], chronic kidney disease (CKD) [73-77], haemolytic-uremic syndrome [78], diabetes [79], hepatic failure [38, 80], malignancy [81, 82], arteritis [83], sepsis [84], fever [1-7], malaria [85], sickle-cell disease [1-3], beta-thalassemia [1-3], Hb-C and G6PD-deficiency [1-3], Wilsons disease [86], as well as advanced age [87]. Eryptosis further increases following erythrocyte storage for transfusion [88].

Accelerated eryptosis leads to anaemia as soon as its rate surpasses the formation of new erythrocytes by erythropoiesis [1-3]. Moreover, eryptotic erythrocytes adhere to the vascular wall thus triggering thrombosis and compromising microcirculation [1-3].

In view of the emerging clinical importance of eryptosis, a detailed description of the methods uncovering and characterizing eryptotic erythrocytes appears desirable. The present paper thus describes flow cytometric methods used in the analysis of eryptosis and the signalling mechanisms involved.

In order to illustrate the results, the respective effects of several xenobiotics known to stimulate eryptosis are shown. Examples are provided by treatment of erythrocytes with the CDC25B phosphatase inhibitor NSC-95397 [35], the PLK1 kinase inhibitor BI-2536 [89], the protease inhibitor Lopinavir [22], the marine sponge-derived Fascaplycin [44], the selective histamine $\mathrm{H} 1$ receptor antagonist Terfenadine [58] and Fucoxanthin (a carotenoid from the chloroplasts of brown seaweeds) [25]. In parallel examples of substances interfering with eryptosis signalling, such as caspase inhibitor Z-VAD-FMK, p38 inhibitor SB203580, protein kinase $\mathrm{C}$ inhibitor staurosporine and casein kinase 1 CK1 $\alpha$ inhibitor D4476 [9] are provided. In those experiments erythrocytes were incubated for 48 hours in Ringer solution without or with xenobiotics.

\section{Materials}

\section{Erythrocytes}

Blood samples are collected by venopuncture from healthy donors in lithium-heparin tubes. The tubes are kept at room temperature $\left(20-25^{\circ} \mathrm{C}\right)$. For this study blood was kindly provided by the blood bank of the University of Tübingen. The study is approved by the ethics committee of the University of Tübingen (184/2003 V).

Flow cytometer

Cytofluorometer FACSCalibur (BD, San José, USA) equipped with a $488 \mathrm{~nm}$-blue laser and controlled by the BD CellQuest ${ }^{\mathrm{TM}}$ Pro software (BD Biosciences). 


\section{Cellular Physiology Cell Physiol Biochem 2017;43:431-444

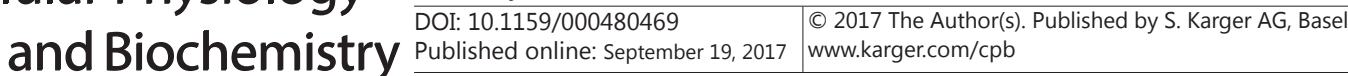 \\ Jemaà et al:: Methods in the Analysis of Eryptosis}

Software

CellQuest ${ }^{\mathrm{TM}}$ Pro software (BD Biosciences), Microsoft Excel (Microsoft) for data analysis and GraphPad Prism (GraphPad) for test of statistical significance.

Reagents, compounds, dyes and antibodies

Solutions and chemicals employed include:

1. Ringer solution: highly purified water (distilled water filtered on $0.22 \mu \mathrm{m}$ ) containing (in $\mathrm{mM}$ ) $125 \mathrm{NaCl}, 5 \mathrm{KCl}, 1 \mathrm{MgSO}_{4}, 32 \mathrm{~N}$-2-hydroxyethylpiperazine-N-2-ethanesulfonic acid (HEPES; pH 7.4), 5 glucose, and $1 \mathrm{CaCl}_{2}$.

2. Annexin-V wash solution: highly purified water containing (in $\mathrm{mM}$ ) $125 \mathrm{NaCl}, 5 \mathrm{KCl}, 1$ $\mathrm{MgSO}_{4}, 32 \mathrm{~N}$-2-hydroxyethylpiperazine-N-2-ethanesulfonic acid (HEPES; pH 7.4), 5 glucose, and $1 \mathrm{CaCl}_{2}$.

3. Phosphate buffered saline (PBS) (Sigma Aldrich, Hamburg, Germany).

4. $0.1 \%(\mathrm{w} / \mathrm{v}$ ) Bovine serum albumin (BSA) (Sigma Aldrich, Hamburg, Germany) in PBS.

5. NSC95397 (Sigma Aldrich, Hamburg, Germany).

6. BI-2536 (Selleck Chemicals, München, Germany).

7. Lopinavir (Sigma Aldrich, Hamburg, Germany).

8. Fascaplycin (Santa Cruz Biotechnology, Santa Cruz, CA, USA).

9. Fucoxanthin (Sigma Aldrich, Hamburg, Germany).

10. Terfenadine (Sigma Aldrich, Hamburg, Germany).

11. Ionomycin (Sigma Aldrich, Hamburg, Germany).

12. Necrostatin-1 (Sigma Aldrich, Hamburg, Germany).

13. D4476 (Sigma Aldrich, Hamburg, Germany).

14. zVAD (Tocris bioscience, Bristol, UK).

15. zIETD-fmk (Selleck Chemicals, München, Germany).

16. zDEVD-fmk (Selleck Chemicals, München, Germany).

17. SB203580 (Tocris bioscience, Bristol, UK).

18. Staurosporine (Sigma Aldrich, Hamburg, Germany).

19. Chelerythrine (Sigma Aldrich, Hamburg, Germany).

20. BAPTA-AM (Thermo Fisher Scientific, Darmstadt, Germany).

21. BODIPY 581/591 C11 (Thermo Fisher Scientific, MA, USA).

22. Fluo-3 AM (Biotium, Hayward, USA).

23. 2',7'-dichlorodihydrofluorescein diacetate (DCFDA) (Sigma, Schnelldorf, Germany).

24. Mercury orange (Sigma-Aldrich, Hamburg, Germany).

25. Annexin-V FITC (ImmunoTools, Friesoythe, Germany).

26. Anti-ceramide (clone MID 15B4; Alexis, Grünberg, Germany).

27. FITC-conjugated goat Anti-Mouse IgG (H+L) (BD Pharmingen, Hamburg, Germany).

\section{Experimental procedures}

Erythrocytes preparation

It is important to work with fresh blood to avoid any unspecific results due to storage and manipulation of erythrocytes.

1. Mix $1 \mathrm{ml}$ of blood with $3 \mathrm{ml}$ of Ringer solution into a $5 \mathrm{ml} \mathrm{FACS}$ tube

2. Centrifuge for $20 \mathrm{~min}$ at $120 \mathrm{~g}$ at $21^{\circ} \mathrm{C}$ with zero deceleration for an optimal separation of erythrocytes

3. Discard supernatant that contains Ringer, platelets and leukocytes, the rest is erythrocytes.

4. Slowly recuperate $300 \mu \mathrm{l}$ from the bottom of the tube and transfer it into a $1.5 \mu \mathrm{l}$ microcentrifuge tube and keep in fridge at $4^{\circ} \mathrm{C}$ for maximum $24 \mathrm{~h}$.

Quantification of cell size

To explore the cell size, erythrocyte volume is estimated from forward scatter (FSC). A histogram SSC-linear vs. FSC-linear is made and the value of Geo Mean of FSC to around 


\section{Cellular Physiology Cell Physiol Biochem 2017;43:431-444 \begin{tabular}{l|l|l} 
DOI: 1011159/000480469 & $\begin{array}{l}\text { (c) } 2017 \text { The Author(s). Published by S. Karger AG, Basel } \\
\text { www.karger.com/cpb }\end{array}$
\end{tabular} Jemaà et al.: Methods in the Analysis of Eryptosis}

Fig. 1. Effect of NSC-95397, Bi-2536 and Fascaplycin on erythrocyte forward scatter. A. Original histograms of forward scatter of erythrocytes following exposure for 48 hours to Ringer solution without (grey area) and with presence of $10 \mu \mathrm{M}$ NSC-95397 (red line), 50 $\mu \mathrm{M}$ Bi-2536 (blue line) or $15 \mu \mathrm{M}$ Fascaplycin (green line). B. Arithmetic means \pm SEM ( $n=$ 12) of the erythrocyte forward scatter (FSC) following incubation for 48 hours to Ringer solution without (grey bar) or with (white bars) $10 \mu \mathrm{M}$ NSC-95397 (red line), $50 \mu \mathrm{M}$ Bi-2536 (blue line) or $15 \mu \mathrm{M}$ Fascaplycin (green line). C,D. Percentage of erythrocytes with (C) FSC< 200 or (D) FSC $>800$ following incubation for 48 hours to Ringer solution without (grey bar) or with (white bars) $10 \mu \mathrm{M}$ NSC-95397 (red line), $50 \mu \mathrm{M}$ Bi-2536 (blue line) or $15 \mu \mathrm{M}$

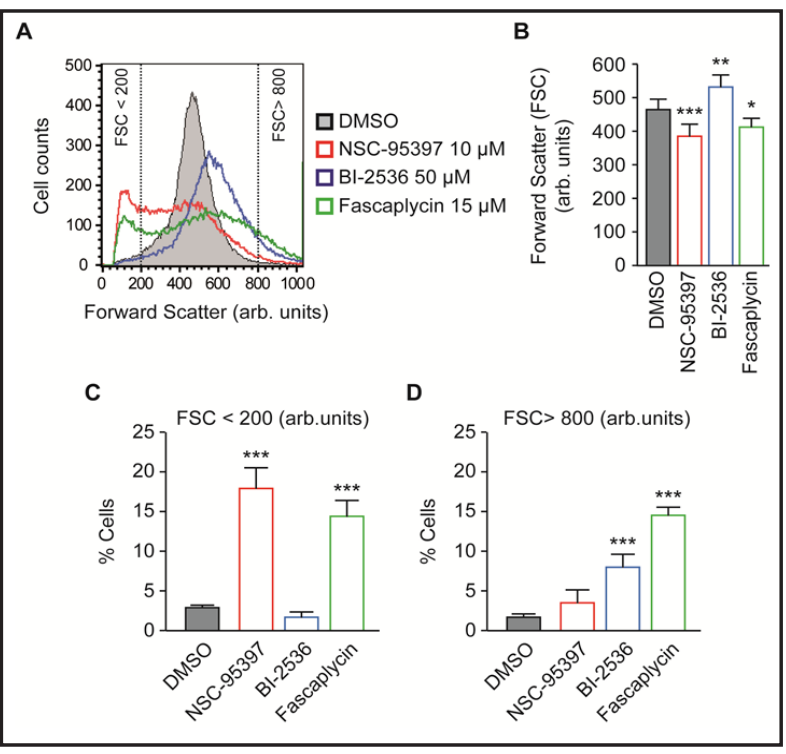
Fascaplycin (green line). ${ }^{*}(p<0.05),{ }^{* *}(p<0.01),{ }^{* * *}(p<0.001)$ indicates significant difference from the absence of drugs treatment (ANOVA).

500 (arbitrary units) fixed. Cell shrinkage is reflected by a decrease and cell swelling by an increase in the geo mean of forward scatter.

1. Prepare the eryptosis inducing agents at the desired concentrations in Ringer solution (NSC-95397 at $10 \mu \mathrm{M}, \mathrm{BI}-2536$ at $50 \mu \mathrm{M}$ and Fascaplycin at $15 \mu \mathrm{M}$ ).

2. For each concentration prepare 1 tube of $1 \mathrm{ml}$ solution.

3. For each tube add $4 \mu \mathrm{l}$ of erythrocytes and mix well by pipetting then gentle vortex.

4. Incubate tubes in standard culture condition $\left(37^{\circ} \mathrm{C}, 5 \% \mathrm{CO}\right)$.

5 . Upon $48 \mathrm{~h}$ of incubation mix gently the cells and transfer $150 \mu \mathrm{l}$ of each tube into a 1 ml FACS tube.

6. Place the " 1 ml FACS tube" into a $5 \mathrm{ml}$ FACS tube.

7. Acquire and analyze samples by means of a classic cytofluorometer allowing the acquisition of light scattering data. The data could be displayed as arithmetic means or as the percentage of erythrocytes undergoing shrinkage or swelling, whereby a threshold for shrunken (e.g. $<200$ ) and swollen (e.g.>800) erythrocytes is defined.

Example: Treatment with the CDC25B inhibitor NSC-95397 is followed by a decrease of cell volume reflected by a decrease of forward scatter (Fig 1A,B). Moreover, the substance increases the percentage of severely shrunken cells (Fig. 1C). Similarly, Fascaplycin treatment is followed by decrease of average forward scatter (Fig. 1B) and increase of the percentage of shrunken cells (Fig. 1C). In contrast, the PLK1 inhibitor BI-2536 leads to increase of average forward scatter (Fig. 1B) and increases the percentage of swollen cells (Fig. 1D). Please note that treatment with Fascaplycin increases both, the percentage of shrunken and the percentage of swollen erythrocytes (Fig. 1A, C and D).

\section{Quantification of phosphatidylserine exposure}

The measurement of scrambling and phosphatidylserine exposure to the cell surface is performed using annexin-V-binding. For staining with annexinV-FITC $150 \mu$ l erythrocyte suspension are washed in Ringer solution containing $5 \mathrm{mM} \mathrm{CaCl}_{2}$ and then stained with Annexin-V-FITC (1:200 dilution) in this solution at $37^{\circ} \mathrm{C}$ for $15 \mathrm{~min}$ under protection from light. Annexin-V-binding is measured by FACS with an excitation wave length of $488 \mathrm{~nm}$ (blue laser) and an emission wave length of $530 \mathrm{~nm}$ (FL1 channel). The percentage of annexinV-binding erythrocytes is defined by the shift of the FITC signal on the FL1-log channel in treated cells compared to control. 


\section{Cellular Physiology Cell Physiol Biochem 2017;43:431-444

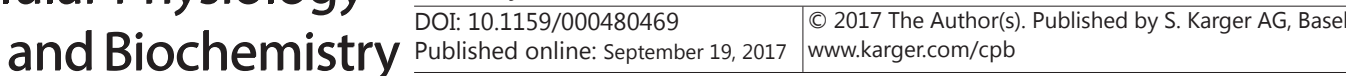 \\ Jemaà et al.: Methods in the Analysis of Eryptosis}

Fig. 2. Effect of NSC-95397, Bi-2536 and Fascaplycin on phosphatidylserine exposure. A. Original histograms of annexin-V-binding of erythrocytes following exposure for 48 hours to Ringer solution without (grey area) and with presence of $10 \mu \mathrm{M}$

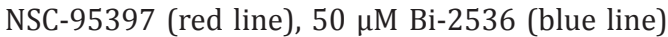
or $15 \mu \mathrm{M}$ Fascaplycin (green line). B. Arithmetic means \pm SEM $(n=12)$ of erythrocytes samples annexin-V-binding following incubation for 48 hours to Ringer solution without (grey bar) or with

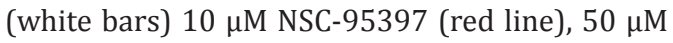

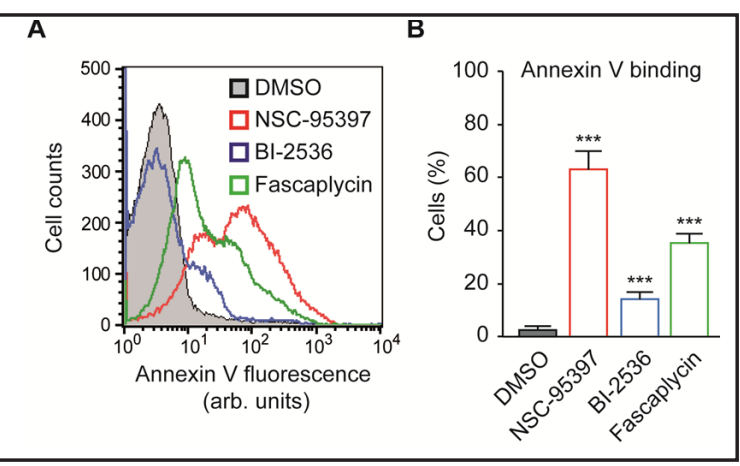
Bi-2536 (blue line) or $15 \mu \mathrm{M}$ Fascaplycin (green line). ${ }^{* * *}(p<0.001)$ indicates significant difference from the absence of drugs treatment (ANOVA).

1. Prepare and incubate the sample tubes as described above (Erythrocytes preparation).

2. Upon $48 \mathrm{~h}$ of incubation mix gently the cells and transfer $150 \mu \mathrm{l}$ of the each tube into a well of 96-well plate.

3. Centrifuge the plate for $3 \mathrm{~min}$ at $120 \mathrm{~g}$ at $21^{\circ} \mathrm{C}$.

4. Remove supernatant and add for each well $100 \mu \mathrm{l}$ solution of annexin-V FITC diluted in annexin-V wash buffer (dilution 1:200).

5. Mix well by pipetting.

6. Transfer the cells into a $1 \mathrm{ml}$ FACS tube.

7. Incubate tubes for $20 \mathrm{~min}$ in standard culture condition $\left(37^{\circ} \mathrm{C}, 5 \% \mathrm{CO} 2\right)$ under protection from light.

8. Place the $1 \mathrm{ml}$ FACS tube into a $5 \mathrm{ml}$ FACS tube and mix well.

9. Acquire and analyze samples by means of a classic cytofluorometer allowing the acquisition of light scattering data and fluorescence recording.

Example: As illustrated in Fig. 2, NSC-95397, BI-2536 and Fascaplycin all markedly enhance the percentage of erythrocytes undergoing cell membrane scrambling. It should be pointed out that none of the three substances triggers hemolysis, which in theory may yield false positive binding of annexin-V.

Quantification of intracellular $\mathrm{Ca}^{2+}$

Cytosolic $\mathrm{Ca}^{2+}$ activity $\left(\left[\mathrm{Ca}^{2+}\right]_{\mathrm{i}}\right)$ is determined utilizing Fluo3 fluorescence [35]. After cells staining with the Fluo-3 AM dye (Biotium, Hayward, USA) (excitation wave length of $488 \mathrm{~nm}$ and emission wavelength of $530 \mathrm{~nm}$ corresponding to the green channel FL1), the Geo mean and the shift of the signal between control and treated cells were evaluated on the FL1-log channel.

1. Prepare and incubate the sample tubes as described above.

2. Remove supernatant and add for each well $100 \mu \mathrm{l}$ solution of $5 \mu \mathrm{M}$ Fluo-3/AM diluted in Ringer buffer.

3. Mix well by pipetting.

4. Transfer the cells into a $1 \mathrm{ml}$ FACS tube.

5. Incubate tubes for $20 \mathrm{~min}$ in standard culture condition $\left(37^{\circ} \mathrm{C}, 5 \% \mathrm{CO}\right)$ under protection from light.

6. Place the $1 \mathrm{ml}$ FACS tube into a $5 \mathrm{ml}$ FACS tube and mix well.

7. Acquire and analyze samples by means of a classic cytofluorometer allowing the acquisition of light scattering data and fluorescence recording.

Examples: Cytosolic $\mathrm{Ca}^{2+}$ activity $\left(\left[\mathrm{Ca}^{2+}\right]_{\mathrm{i}}\right)$ is determined utilizing Fluo3 fluorescence [35]. A histogram and bar graph is shown (Fig. $3 \mathrm{~A}$ and B). To confirm the involvement of cytosolic $\mathrm{Ca}^{2+}$ activity in the eryptosis, cells are incubated in Ringer solution with or without calcium and the difference of death with annexin-V staining in each case quantified (Fig. $3 \mathrm{C}$ and D). Moreover, the cells can be co-treated with the $\mathrm{Ca}^{2+}$ chelator 1,2-Bis(2-aminophenoxy) ethane- $\mathrm{N}, \mathrm{N}, \mathrm{N}^{\prime}, \mathrm{N}^{\prime}$-tetraacetic acid tetrakis (acetoxymethyl ester) BAPTA-AM (Thermo Fisher 
Fig. 3. Effect of drug treatment on erythrocyte cytosolic $\mathrm{Ca}^{2+}$ activity. A. Original histograms of Fluo3 fluorescence in erythrocytes following exposure for 48 hours to Ringer solution without (grey area) and with (green line) presence of $15 \mu \mathrm{M}$ Fascaplycin. B. Arithmetic means \pm SEM ( $n=12$ ) of Fluo3 fluorescence in erythrocytes following incubation for 48 hours to Ringer solution without (grey bar) or with (green line) presence of $15 \mu \mathrm{M}$ Fascaplycin. C. Original histograms of annexin-V-binding of erythrocytes following exposure for 48 hours to Ringer solu-

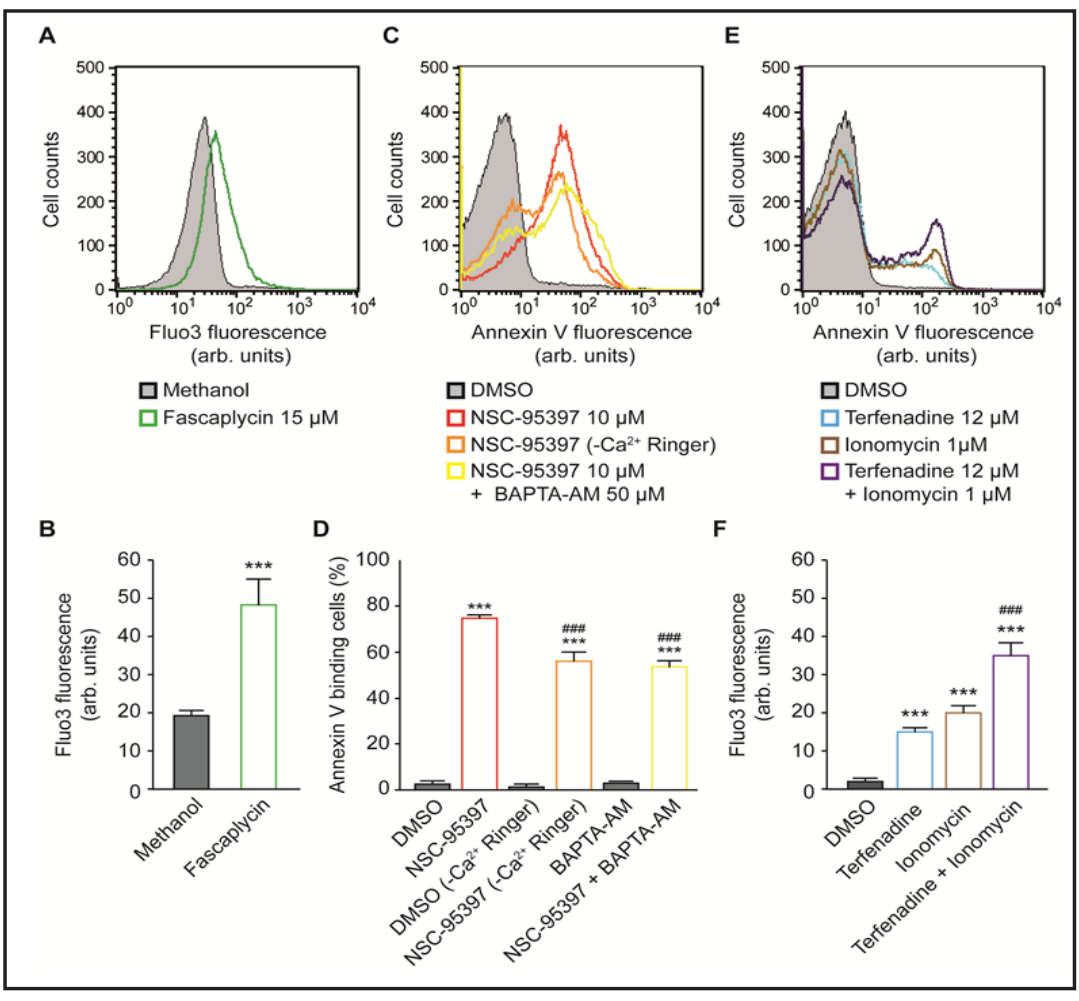

tion without (grey area) and with presence of $10 \mu \mathrm{M}$ NSC-95397 (red line), $10 \mu \mathrm{M}$ NSC-95397 in $\mathrm{Ca}^{2+}$ free solution (orange line) or $10 \mu \mathrm{M}$ NSC-95397 and $\mathrm{Ca}^{2+}$ chelator BAPTA-AM (yellow line). D. Arithmetic means \pm SEM ( $n=12$ ) of annexin-V-binding of erythrocytes following exposure for 48 hours to Ringer solution without (grey bar) and with presence of $10 \mu \mathrm{M}$ NSC-95397 (white bars and red line), $10 \mu \mathrm{M}$ NSC-95397 in $\mathrm{Ca}^{2+}$ free solution (orange line) or $10 \mu \mathrm{M}$ NSC-95397 and $\mathrm{Ca}^{2+}$ chelator BAPTA-AM (yellow line). E. Original histograms of annexin-V-binding of erythrocytes following exposure for 48 hours to Ringer solution without (grey area) and with presence of $12 \mu \mathrm{M}$ Terfenadine (blue line), exposure for 30 minutes to $1 \mu \mathrm{M}$ Ionomycin (brown line) or pre-exposure for 48 hours with $12 \mu \mathrm{M}$ Terfenadine then 30 minutes to $1 \mu \mathrm{M}$ Ionomycin (purple line). F. Arithmetic means \pm SEM $(n=12)$ of annexin-V-binding of erythrocytes following exposure for 48 hours to Ringer solution without (grey bar) and with presence of $12 \mu \mathrm{M}$ Terfenadine (white bar and blue line), exposure for 30 minutes to $1 \mu \mathrm{M}$ Ionomycin (white bar and brown line) or pre-exposure for 48 hours with $12 \mu \mathrm{M}$ Terfenadine then 30 minutes to $1 \mu \mathrm{M}$ Ionomycin (white bar and purple line).*** $(p<0.001)$ indicates significant difference from the absence of treatment (ANOVA). \#\#\# $(p<0.001)$ indicates significant difference from the presence of $\mathrm{Ca}^{2+}$ or absence of $\mathrm{Ca}^{2+}$ chelator BAPTA-AM after $10 \mu \mathrm{M}$ NSC-95397 treatment and significant difference from presence of Ionomycin after $12 \mu \mathrm{M}$ Terfenadine treatment (ANOVA).

Scientific, Darmstadt, Germany) [35] and the difference of death with annexin-V between treated cells and co-treated with BATA-AM evaluated. The NSC-95397 and BAPTA-AM cotreatment decrease eryptosis due to the CDC25B phosphatase inhibitor (Fig. 3 C and D). In contrast, treatment of the cells for 30 minutes with the ionophore Ionomycin [58] after Terfenadine 48 hours pre-incubation increases the cell death and confirms the role of $\mathrm{Ca}^{2+}$ entry as death pathway (Fig. $3 \mathrm{E}$ and F).

\section{Modulation of intracellular $\mathrm{Ca}^{2+}$}

For decreasing $\left[\mathrm{Ca}^{2+}\right]_{\mathrm{i}}$ :

1. Prepare the eryptosis inducing agent(s) at the desired concentrations (10 $\mu \mathrm{M}$ of NSC95397) in the Ringer solution with and without calcium or with addition of $\mathrm{Ca}^{2+}$ chelator BAPTA-AM.

2. For each condition prepare 1 tube of $1 \mathrm{ml}$ solution and perform the annexin-V assay as described above. 


\section{Cellular Physiology Cell Physiol Biochem 2017;43:431-444

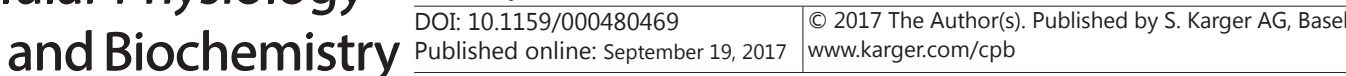 Jemaà et al.: Methods in the Analysis of Eryptosis}

Fig. 4. Effect of Fascaplycin on ROS formation. A. Original histogram of DCF fluorescence in erythrocytes following exposure for 48 hours to Ringer solution without (grey area) and with (green line) presence of Fascaplycin (15 $\mu \mathrm{M})$. B. Arithmetic means \pm SEM $(n=12)$ of the DCF fluorescence (arbitrary units) in erythrocytes exposed for 48 hours to Ringer solution without (grey bar) or with (white bar, green line) Fascaplycin $(15 \mu \mathrm{M}){ }^{* * *}(p<0.001)$ indicates significant difference from the absence of Fascaplycin (ANOVA).

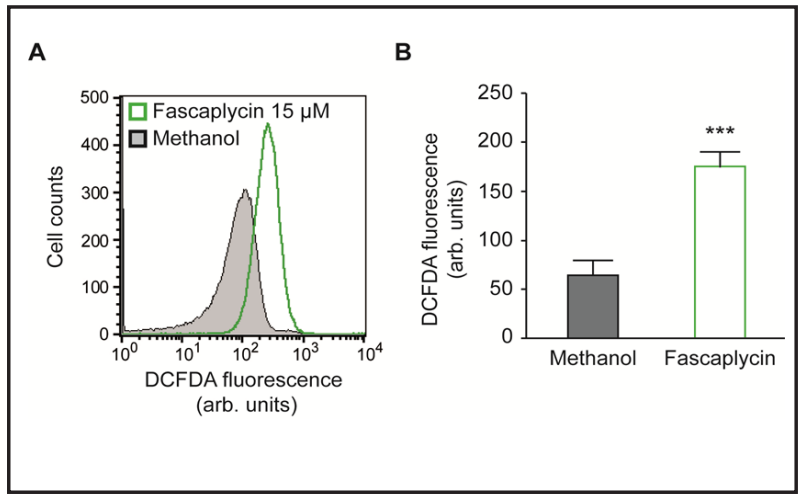

For increasing $\left[\mathrm{Ca}^{2+}\right]_{\mathrm{i}}$ :

1. Prepare the eryptosis inducing agent at the desired concentration in Ringer solution (Terfenadine at $12 \mu \mathrm{M}$ ) and incubate the sample tubes as described above.

2. Upon $48 \mathrm{~h}$ of incubation mix gently the cells and for each tube add $1 \mu \mathrm{M}$ of the ionophore Ionomycin.

3. Incubate tubes for $30 \mathrm{~min}$ in standard culture condition $\left(37^{\circ} \mathrm{C}, 5 \% \mathrm{CO}_{2}\right)$ under protection from light.

4. Perform the annexin-V assay as described above

Quantification of oxidative stress

To quantify oxidative stress, erythrocytes are stained with the $2^{\prime}, 7^{\prime}$-dichlorodihydrofluorescein diacetate (DCFDA) (Sigma, Schnelldorf, Germany) to measure the reactive oxygen species (ROS) [90]. DCFDA is non-fluorescent, but in the presence of ROS, it is oxidized and becomes green fluorescent. Geo mean is used to quantify ROS on the FL1-log channel.

1. Prepare the eryptosis inducing agent at the desired concentrations in Ringer solution (Fascaplycin at $15 \mu \mathrm{M}$ ).

2. Incubate the sample tubes as described above.

3. Remove supernatant and add for each well $100 \mu$ l solution of $10 \mu \mathrm{M}$ DCFDA diluted in PBS.

4. Mix well by pipetting.

5. Transfer the cells into a $1 \mathrm{ml} \mathrm{FACS} \mathrm{tube.}$

6. Incubate tubes for $20 \mathrm{~min}$ in standard culture condition $\left(37^{\circ} \mathrm{C}, 5 \% \mathrm{CO}_{2}\right)$ under protection from light.

7. Place the $1 \mathrm{ml} \mathrm{FACS}$ tube into $5 \mathrm{ml}$ FACS tube and mix well.

8. Acquire and analyze samples by means of a classic cytofluorometer allowing the acquisition of light scattering data and fluorescence recording.

Example: Original histogram and arithmetic means \pm SEM of DCF fluorescence in erythrocytes following exposure for 48 hours to Ringer solution without and with presence of Fascaplycin $(15 \mu \mathrm{M})$ is shown in Fig. 4.

Quantification of reduced glutathione abundance

Erythrocytes depend on protection of antioxidant glutathione (GSH) against oxidative stress and reactive oxygen species [91]. A decrease of GSH can be a hallmark of eryptosis due to oxidative stress [92]. To quantify GSH, mercury orange 1(4-chloromercuryphenylazo-2-naphthol) (Sigma-Aldrich, Hamburg, Germany) [93] is used. The reaction between mercury orange and GSH leads to emitted intense red fluorescence when excited with the blue laser (excitation wavelength of $488 \mathrm{~nm}$ ). The fluorescence can be measured on the FL2log channel (emission wavelength of $576 \mathrm{~nm}$ ). Geo mean is used to calculate the value of GSH in control or in the treated cells.

1. Prepare the eryptosis inducing agent at the desired concentrations in Ringer solution (Lopinavir at $40 \mu \mathrm{M}$ ). 


\section{Cellular Physiology Cell Physiol Biochem 2017;43:431-444 \begin{tabular}{l|l|l} 
DOI: 10.1159/000480469 & $\begin{array}{l}\text { (c) } 2017 \text { The Author(s). Published by S. Karger AG, Basel } \\
\text { www.karger.com/cpb }\end{array}$
\end{tabular} Jemaà et al.: Methods in the Analysis of Eryptosis}

Fig. 5. Effect of Lopinavir on erythrocyte GSH level. A. Original histogram of mercury orange fluorescence of erythrocytes following exposure for 48 hours to Ringer solution without (grey area) and with (orange line) presence of Lopinavir $(40 \mu \mathrm{M})$. B. Arithmetic means \pm SEM $(n=12)$ of the mercury orange fluorescence of erythrocytes following exposure for 48 hours to Ringer solution without (white bar and grey line) and with (white bar and orange line) presence of Lopina$\operatorname{vir}(40 \mu \mathrm{M}) .{ }^{* * *}(p<0.001)$ indicates significant difference from the absence of Lopinavir (ANOVA).

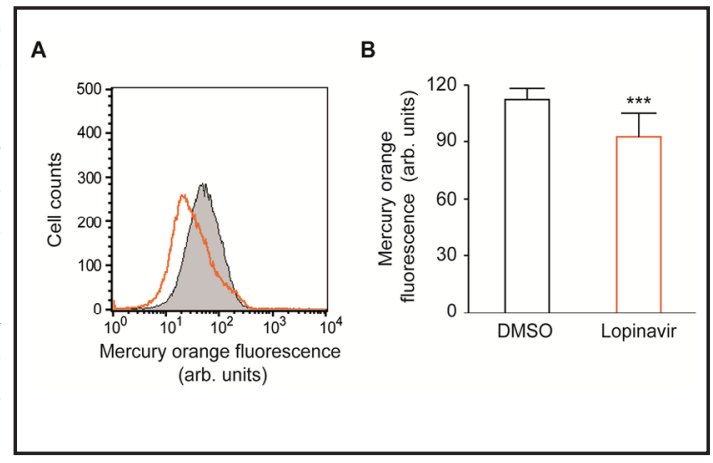

2. Incubate the sample tubes as described above.

3. Remove supernatant and add for each well $100 \mu \mathrm{l}$ solution of $40 \mu \mathrm{M}$ mercury orange diluted in PBS.

4. Mix well by pipetting.

5. Transfer the cells into a $1 \mathrm{ml}$ FACS tube.

6. Incubate tubes for $20 \mathrm{~min}$ in standard culture conditions $\left(37^{\circ} \mathrm{C}, 5 \% \mathrm{CO}_{2}\right)$ under protection from light.

7. Place the $1 \mathrm{ml}$ FACS tube into $5 \mathrm{ml}$ FACS tube and mix well.

8. Acquire and analyze samples by means of a classic cytofluorometer allowing the acquisition of light scattering data and fluorescence recording.

Example: Lopinavir treatment [22] induces oxidative stress and reduction of antioxidant glutathione as shown in Fig. 5.

\section{Quantification of lipid peroxidation}

Oxidative stress induces also damage on erythrocytic membrane lipids [94]. The polyunsaturated fatty acids are subject to oxidization by lipid peroxyl radicals and ROS, resulting in the formation of lipid hydroperoxides [95]. This reaction is commonly named lipid peroxidation [96]. In order to quantify this membrane damage, the dye BODIPY 581/591 C11 (Thermo Fisher Scientific, MA, USA) is used [97]. This dye is a fatty acid analogue with particular fluorescent properties. After excitation with the blue laser (488 nm), it emits in the red range of visible spectrum (maximum of $595 \mathrm{~nm}$ ) but once ROS are oxidized, it shifts into the green range $(510 \mathrm{~nm})$. The lipid peroxidation is quantified by measuring the Geo mean on both FL1-log and FL2-log channel.

1. Prepare the eryptosis inducing agent at the desired concentrations in Ringer solution (Fucoxanthin at $80 \mu \mathrm{M}$ ) and incubate the sample tubes as described above.

2. Upon $48 \mathrm{~h}$ of incubation mix gently the cells and for each tube add $5 \mu \mathrm{M}$ BODIPY $581 / 591 \mathrm{C} 11$.

3. Incubate tubes for $30 \mathrm{~min}$ in standard culture condition $\left(37^{\circ} \mathrm{C}, 5 \% \mathrm{CO}_{2}\right)$ under protection from light.

4. Mix gently the cells and transfer $150 \mu \mathrm{l}$ of the each tube into $1 \mathrm{ml}$ FACS tube.

5. Place the $1 \mathrm{ml} \mathrm{FACS}$ tube into a $5 \mathrm{ml}$ FACS tube and mix well.

6. Acquire and analyze samples by means of a classic cytofluorometer allowing the acquisition of light scattering data and fluorescence recording.

Example: Original histogram and arithmetic means \pm SEM of BODIPY 581/591 C11 fluorescence at $530 \mathrm{~nm}$ emission wavelength following exposure for 48 hours to Ringer solution without and with presence of $80 \mu \mathrm{M}$ Fucoxanthin is shown in Fig. 6.

\section{Quantification of ceramide abundance}

Ceramide is another important stimulator of the eryptosis [98]. Ceramide is generated by breakdown of cell membrane sphingomyelin and sensitizes erythrocytes to the enhanced intracellular calcium concentration [99]. The abundance of ceramide the erythrocyte surface can be measured utilizing specific antibodies. 


\section{Cellular Physiology Cell Physiol Biochem 2017;43:431-444 \begin{tabular}{l|l|l} 
DOI: 10.1159/000480469 & $\begin{array}{l}\text { O } 2017 \text { The Author(s). Published by S. Karger AG, Basel } \\
\text { www.karger.com/cpb }\end{array}$
\end{tabular} \\ Jemaà et al.: Methods in the Analysis of Eryptosis}

Fig. 6. Effect of Fucoxanthin on lipid peroxidation. A. Original histogram of BODIPY 581/591 C11 fluorescence at $530 \mathrm{~nm}$ emission wavelength (FL1 channel) following exposure for 48 hours to Ringer solution without (grey area) and with (green line) presence of $80 \mu \mathrm{M}$ Fucoxanthin. B. Arithmetic means \pm SEM ( $n=$ 12) of the BODIPY 581/591 C11 fluorescence at $530 \mathrm{~nm}$ emission wavelength (arbitrary units) in erythrocytes exposed for 48 hours to Ringer solution without (grey bar) or with (white bar and green line) $80 \mu \mathrm{M}$ Fucoxanthin. C. Original histogram of BODIPY 581/591 C11 fluorescence at $585 \mathrm{~nm}$ emission wavelength (FL2 channel) following exposure for 48 hours to Ringer solution without (white bar and grey line) and with (red line) presence of $80 \mu \mathrm{M} \mathrm{Fu}$ coxanthin. D. Arithmetic means \pm SEM $(n=12)$ of the BODIPY 581/591 C11 fluorescence at $585 \mathrm{~nm}$ emission wavelength (arbitrary units) in erythrocytes exposed for 48 hours to Ringer solution without (grey bar) or with (white bar and red line) $80 \mu \mathrm{M}$ Fucoxanthin. ${ }^{* * *}(p<0.001)$ indicates significant difference from the $a b$ sence of Fucoxanthin (ANOVA).
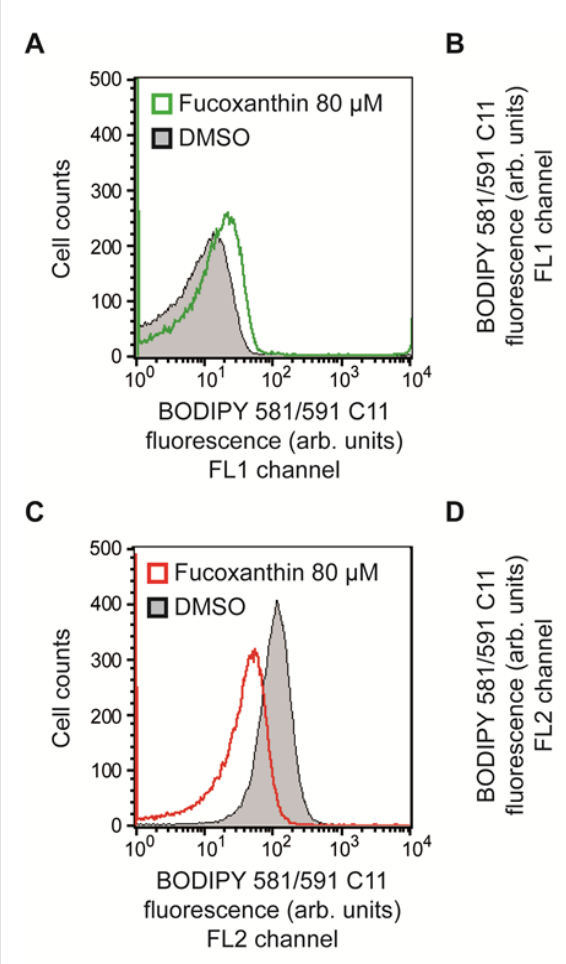

D
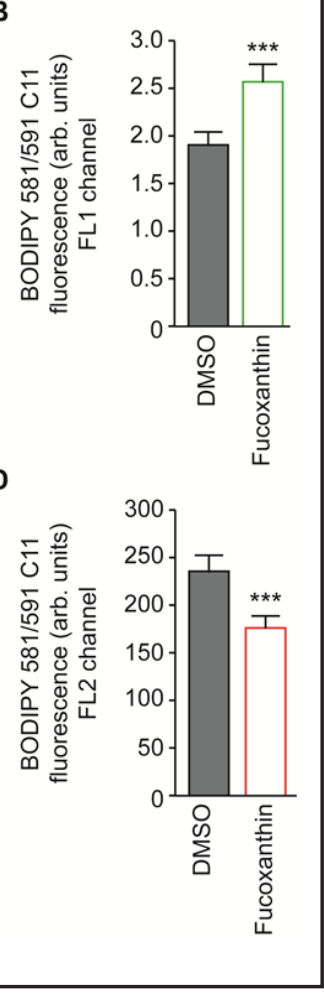

1. Prepare the eryptosis inducing agent at the desired concentrations in Ringer solution (Fascaplycin at $15 \mu \mathrm{M}$ ) and incubate the sample tubes as described above.

2. Remove supernatant and add for each well $100 \mu \mathrm{l}$ of a solution containing the primary anti-ceramide antibody diluted 1:10 in $0.1 \%(\mathrm{w} / \mathrm{v})$ BSA in PBS or with $100 \mu \mathrm{L}$ of $1 \%(\mathrm{w} / \mathrm{v}$ ) BSA in PBS as negative staining control.

3.Incubate tubes for $60 \mathrm{~min}$ in standard culture condition $\left(37^{\circ} \mathrm{C}, 5 \% \mathrm{CO}_{2}\right)$ under protection from light.

4. Wash twice with $0.1 \%(\mathrm{w} / \mathrm{v}$ ) PBS-BSA by centrifuging for $3 \mathrm{~min}$ at $120 \mathrm{~g}$ at room temperature.

5. Remove supernatant and add $100 \mu \mathrm{L}$ of a solution containing FITC-conjugated goat anti-mouse antibody diluted 1:50 in $0.1 \%(\mathrm{w} / \mathrm{v})$ BSA in PBS.

6.Incubate tubes for $30 \mathrm{~min}$ in standard culture condition $\left(37^{\circ} \mathrm{C}, 5 \% \mathrm{CO}_{2}\right)$ under protection from light.

7. Wash twice with $0.1 \%(\mathrm{w} / \mathrm{v})$ PBS-BSA by centrifuging for 3 min at $120 \mathrm{~g}$ at room temperature.

8. Transfer the cells into a $1 \mathrm{ml}$ FACS tube.

9. Place the $1 \mathrm{ml}$ FACS tube into $5 \mathrm{ml}$ FACS tube and mix well.

10. Acquire and analyze samples by means of a classic cytofluorometer allowing the acquisition of light scattering data and fluorescence recording.

Example: Original histogram and arithmetic means \pm SEM of ceramide abundance in erythrocytes following exposure for 48 hours to Ringer solution without and with presence of Fascaplycin $(15 \mu \mathrm{M})$ is shown in Fig. 7.

Uncovering involvement of kinases in the signaling of eryptosis

Erythrocytes harbor a variety of functional enzymes that stimulate eryptosis, such as caspase 8 and 3 [100], casein kinase $1 \alpha$ [101], protein kinase C [102], and p38 kinase [2]. Moreover, eryptosis and RBC necroptosis share several features [103]. To evaluate the involvement of enzymes in eryptosis, cells are cotreated with death inducing agents and the 


\section{Cellular Physiology Cell Physiol Biochem 2017;43:431-444

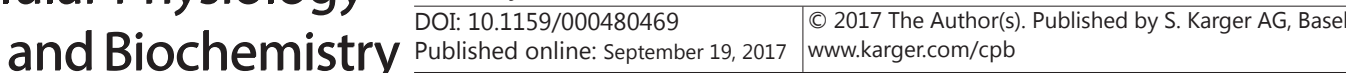 \\ Jemaà et al.: Methods in the Analysis of Eryptosis}

Fig. 7. Effect of Fascaplycin on ceramide abundance at the erythrocyte surface. A. Original histogram of ceramide abundance in erythrocytes following exposure for 48 hours to Ringer solution without (grey area) and with (green line) presence of Fascaplycin $(15 \mu \mathrm{M})$. B. Arithmetic means \pm SEM $(n=12)$ of the ceramide abundance (arbitrary units) in erythrocytes exposed for 48 hours to Ringer solution without (grey bar) or with (white bar and green line) Fascaplycin

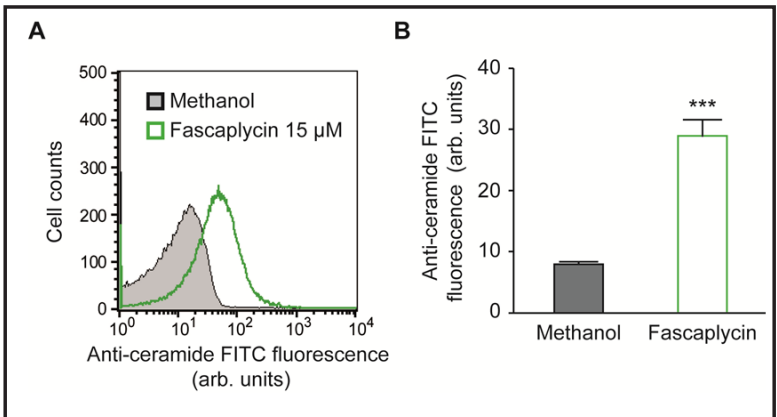
$(15 \mu \mathrm{M}) .{ }^{* * *}(p<0.001)$ indicates significant difference from the absence of Fascaplycin $(15 \mu \mathrm{M})$.

respective inhibitors, such as $10 \mu \mathrm{M}$ of the pan-caspase inhibitor zVAD, $50 \mu \mathrm{M}$ of the caspase 8 inhibitor zIETD-fmk, $50 \mu \mathrm{M}$ of the caspase 3 inhibitor zDEVD-fmk, $10 \mu \mathrm{M}$ of the casein kinase $1 \alpha$ inhibitor D4476, $2 \mu \mathrm{M}$ of the p38 kinase inhibitor SB203580, $1 \mu \mathrm{M}$ of the protein kinase $\mathrm{C}$ inhibitor staurosporine, $10 \mu \mathrm{M}$ of the protein kinase $\mathrm{C}$ inhibitor chelerythrine, or $100 \mu \mathrm{M}$ of the necroptosis inhibitor necrostatin-1. Phosphatidylserine exposure at the surface is measured after 48 hours of incubation of the cells with the respective chemicals using annexin-V-binding (see above).

\section{Conclusions}

Eryptosis is the suicidal death of erythrocytes, cells lacking nuclei and mitochondria. Eryptosis shares some hallmarks of nucleated cell apoptosis, essentially cell shrinkage, phosphatidylserine exposure, membrane blebbing, and elevated ROS (reactive oxygen species) levels $[2,7,90,102]$. The present paper outlines protocols that can be routinely used to assess eryptosis by Flow Cytometry, a powerful technique, allowing analysis of a large number of individual cells within short times. We highly recommend the described technology for further studies on triggers, inhibitors and mechanisms of this fundamental biological process with highest clinically relevance.

\section{Acknowledgements}

The authors gratefully acknowledge the meticulous preparation of the manuscript by Lejla Subasic. The study was supported by the Deutsche Forschungsgemeinschaft and Open Access Publishing Fund of Tuebingen University. Work of R.B. is supported by the Institutional Strategy of the University of Tuebingen (Deutsche Forschungsgemeinschaft, ZUK63). The authors acknowledge the Young Tunisian Researchers in Biology YTRB Network for the logistic help.

\section{Disclosure Statement}

The authors declare no conflict of interest.

\section{References}

1 Lang E, Qadri SM, Lang F: Killing me softly - suicidal erythrocyte death. Int J Biochem Cell Biol 2012;44:1236-1243.

2 Lang E, Lang F: Mechanisms and pathophysiological significance of eryptosis, the suicidal erythrocyte death. Semin Cell Dev Biol 2015;39:35-42.

-3 Lang F, Gulbins E, Lerche H, Huber SM, Kempe DS, Foller M: Eryptosis, a window to systemic disease. Cell Physiol Biochem 2008;22:373-380.

-4 Briglia M, Antonia Rossi M, Faggio C: Eryptosis: Ally or Enemy. Curr Med Chem 2016; 


\section{Cellular Physiology Cell Physiol Biochem 2017;43:431-444 \begin{tabular}{l|l|l} 
and BOI: 101159/000480469 & $\begin{array}{l}\text { C } 2017 \text { The Author(s). Published by S. Karger AG, Basel } \\
\text { www.karger.com/cpb }\end{array}$
\end{tabular} \\ Jemaà et al.: Methods in the Analysis of Eryptosis}

5 Gusev GP, Govekar R, Gadewal N, Agalakova NI: Understanding quasi-apoptosis of the most numerous enucleated components of blood needs detailed molecular autopsy. Ageing Res Rev 2017;35:46-62.

6 Lang E, Bissinger R, Qadri SM, Lang F: Suicidal death of erythrocytes in cancer and its chemotherapy: A potential target in the treatment of tumor-associated anemia. Int J Cancer 2017;10.1002/ijc.30800

7 Lang F, Qadri SM: Mechanisms and significance of eryptosis, the suicidal death of erythrocytes. Blood Purif 2012;33:125-130.

-8 Foller M, Huber SM, Lang F: Erythrocyte programmed cell death. IUBMB Life 2008;60:661-668.

-9 Lang E, Lang F: Triggers, inhibitors, mechanisms, and significance of eryptosis: the suicidal erythrocyte death. Biomed Res Int 2015;2015:513518.

-10 Al Mamun Bhuyan A, Bissinger R, Cao H, Lang F: Triggering of Suicidal Erythrocyte Death by Bexarotene. Cell Physiol Biochem 2016;40:1239-1251.

11 Al Mamun Bhuyan A, Bissinger R, Stockinger K, Lang F: Stimulation of Suicidal Erythrocyte Death by Tafenoquine. Cell Physiol Biochem 2016;39:2464-2476.

12 Al Mamun Bhuyan A, Signoretto E, Bissinger R, Lang F: Enhanced Eryptosis Following Exposure to Dolutegravir. Cell Physiol Biochem 2016;39:639-650.

13 Al Mamun Bhuyan A, Signoretto E, Lang F: Triggering of Suicidal Erythrocyte Death by Psammaplin A. Cell Physiol Biochem 2016;39:908-918.

14 Almasry M, Jemaa M, Mischitelli M, Faggio C, Lang F: Stimulation of Suicidal Erythrocyte Death by Phosphatase Inhibitor Calyculin A. Cell Physiol Biochem 2016;40:163-171.

15 Alzoubi K, Egler J, Abed M, Lang F: Enhanced eryptosis following auranofin exposure. Cell Physiol Biochem 2015;37:1018-1028.

16 Bissinger R, Barking S, Alzoubi K, Liu G, Liu G, Lang F: Stimulation of Suicidal Erythrocyte Death by the Antimalarial Drug Mefloquine. Cell Physiol Biochem 2015;36:1395-1405.

-17 Bissinger R, Bhuyan AA, Signoretto E, Lang F: Stimulating Effect of Elvitegravir on Suicidal Erythrocyte Death. Cell Physiol Biochem 2016;38:1111-1120.

18 Bissinger R, Bouguerra G, Al Mamun Bhuyan A, Waibel S, Abbes S, Lang F: Efavirenz Induced Suicidal Death of Human Erythrocytes. Cell Physiol Biochem 2015;37:2496-2507.

19 Bissinger R, Bouguerra G, Stockinger K, Abbes S, Lang F: Triggering of Suicidal Erythrocyte Death by Topotecan. Cell Physiol Biochem 2015;37:1607-1618.

-20 Bissinger R, Modicano P, Alzoubi K, Honisch S, Faggio C, Abed M, Lang F: Effect of saponin on erythrocytes. Int J Hematol 2014;100:51-59.

-21 Bissinger R, Modicano P, Frauenfeld L, Lang E, Jacobi J, Faggio C, Lang F: Estramustine-induced suicidal erythrocyte death. Cell Physiol Biochem 2013;32:1426-1436.

-22 Bissinger R, Waibel S, Bouguerra G, Al Mamun Bhuyan A, Abbes S, Lang F: Enhanced Eryptosis Following Exposure to Lopinavir. Cell Physiol Biochem 2015;37:2486-2495.

-23 Bouguerra G, Aljanadi O, Bissinger R, Abbes S, Lang F: Embelin-Induced Phosphatidylserine Translocation in the Erythrocyte Cell Membrane. Cell Physiol Biochem 2015;37:1629-1640.

24 Bouguerra G, Bissinger R, Abbes S, Lang F: Stimulation of Eryptosis by Narasin. Cell Physiol Biochem 2015;37:1807-1816.

-25 Briglia M, Calabro S, Signoretto E, Alzoubi K, Laufer S, Faggio C, Lang F: Fucoxanthin Induced Suicidal Death of Human Erythrocytes. Cell Physiol Biochem 2015;37:2464-2475.

-26 Briglia M, Fazio A, Faggio C, Lang F: Triggering of Suicidal Erythrocyte Death by Zosuquidar. Cell Physiol Biochem 2015;37:2355-2365.

27 Briglia M, Fazio A, Faggio C, Laufer S, Alzoubi K, Lang F: Triggering of Suicidal Erythrocyte Death by Ruxolitinib. Cell Physiol Biochem 2015;37:768-778.

28 Briglia M, Fazio A, Signoretto E, Faggio C, Lang F: Edelfosine Induced Suicidal Death of Human Erythrocytes. Cell Physiol Biochem 2015;37:2221-2230.

29 Calabro S, Alzoubi K, Faggio C, Laufer S, Lang F: Triggering of Suicidal Erythrocyte Death Following Boswellic Acid Exposure. Cell Physiol Biochem 2015;37:131-142.

-30 Egler J, Lang F: Licochalcone A Induced Suicidal Death of Human Erythrocytes. Cell Physiol Biochem 2015;37:2060-2070.

-31 Egler J, Zierle J, Lang F: Stimulating Effect of Manumycin A on Suicidal Erythrocyte Death. Cell Physiol Biochem 2016;38:1147-1156.

32 Faggio C, Alzoubi K, Calabro S, Lang F: Stimulation of suicidal erythrocyte death by PRIMA-1. Cell Physiol Biochem 2015;35:529-540. 


\section{Cellular Physiology Cell Physiol Biochem 2017;43:431-444 \begin{tabular}{l|l|l|l} 
DOI: 101159/000480469 & $\begin{array}{l}\text { O } 2017 \text { The Author(s). Published by S. Karger AG, Basel } \\
\text { wwww.karger.com/cpb }\end{array}$
\end{tabular} \\ Jemaà et al.: Methods in the Analysis of Eryptosis}

33 Fazio A, Briglia M, Faggio C, Alzoubi K, Lang F: Stimulation of Suicidal Erythrocyte Death by Garcinol. Cell Physiol Biochem 2015;37:805-815.

34 Fazio A, Briglia M, Faggio C, Alzoubi K, Lang F: Oxaliplatin Induced Suicidal Death of Human Erythrocytes. Cell Physiol Biochem 2015;37:2393-2404.

35 Jemaa M, Mischitelli M, Fezai M, Almasry M, Faggio C, Lang F: Stimulation of Suicidal Erythrocyte Death by the CDC25 Inhibitor NSC-95397. Cell Physiol Biochem 2016;40:597-607.

-36 Lang E, Jilani K, Bissinger R, Rexhepaj R, Zelenak C, Lupescu A, Lang F, Qadri SM: Vitamin D-Rich Diet in Mice Modulates Erythrocyte Survival. Kidney Blood Press Res 2015;40:403-412.

-37 Lang E, Modicano P, Arnold M, Bissinger R, Faggio C, Abed M, Lang F: Effect of thioridazine on erythrocytes. Toxins (Basel) 2013;5:1918-1931.

-38 Lang E, Pozdeev VI, Gatidis S, Qadri SM, Haussinger D, Kubitz R, Herebian D, Mayatepek E, Lang F, Lang KS, Lang PA: Bile Acid-Induced Suicidal Erythrocyte Death. Cell Physiol Biochem 2016;38:1500-1509.

39 Lang E, Zelenak C, Eberhard M, Bissinger R, Rotte A, Ghashghaeinia M, Lupescu A, Lang F, Qadri SM: Impact of cyclin-dependent kinase CDK4 inhibition on eryptosis. Cell Physiol Biochem 2015;37:1178-1186.

40 Macczak A, Cyrkler M, Bukowska B, Michalowicz J: Eryptosis-inducing activity of bisphenol A and its analogs in human red blood cells (in vitro study). J Hazard Mater 2016;307:328-335.

41 Mischitelli M, Jemaa M, Almasry M, Faggio C, Lang F: Stimulation of Erythrocyte Cell Membrane Scrambling by Quinine. Cell Physiol Biochem 2016;40:657-667.

42 Mischitelli M, Jemaa M, Almasry M, Faggio C, Lang F: Stimulation of Suicidal Erythrocyte Death by Rottlerin. Cell Physiol Biochem 2016;40:558-566.

43 Mischitelli M, Jemaa M, Almasry M, Faggio C, Lang F: Triggering of Erythrocyte Cell Membrane Scrambling by Emodin. Cell Physiol Biochem 2016;40:91-103.

44 Mischitelli M, Jemaa M, Almasry M, Faggio C, Lang F: Triggering of Suicidal Erythrocyte Death by Fascaplysin. Cell Physiol Biochem 2016;39:1638-1647.

45 Mischitelli M, Jemaa M, Almasry M, Faggio C, Lang F: Ca2+ Entry, Oxidative Stress, Ceramide and Suicidal Erythrocyte Death Following Diosgenin Treatment. Cell Physiol Biochem 2016;39:1626-1637.

46 Officioso A, Alzoubi K, Lang F, Manna C: Hydroxytyrosol inhibits phosphatidylserine exposure and suicidal death induced by mercury in human erythrocytes: Possible involvement of the glutathione pathway. Food Chem Toxicol 2016;89:47-53.

47 Officioso A, Alzoubi K, Manna C, Lang F: Clofazimine Induced Suicidal Death of Human Erythrocytes. Cell Physiol Biochem 2015;37:331-341.

48 Officioso A, Manna C, Alzoubi K, Lang F: Bromfenvinphos induced suicidal death of human erythrocytes. Pestic Biochem Physiol 2016;126:58-63.

49 Pagano M, Faggio C: The use of erythrocyte fragility to assess xenobiotic cytotoxicity. Cell Biochem Funct 2015;33:351-355.

50 Peter T, Bissinger R, Enkel S, Alzoubi K, Oswald G, Lang F: Programmed erythrocyte death following in vitro Treosulfan treatment. Cell Physiol Biochem 2015;35:1372-1380.

-51 Peter T, Bissinger R, Lang F: Stimulation of Eryptosis by Caspofungin. Cell Physiol Biochem 2016;39:939949.

52 Peter T, Bissinger R, Liu G, Lang F: Anidulafungin-Induced Suicidal Erythrocyte Death. Cell Physiol Biochem 2016;38:2272-2284.

53 Peter T, Bissinger R, Signoretto E, Mack AF, Lang F: Micafungin-Induced Suicidal Erythrocyte Death. Cell Physiol Biochem 2016;39:584-595.

54 Pretorius E, du Plooy JN, Bester J: A Comprehensive Review on Eryptosis. Cell Physiol Biochem 2016;39:1977-2000.

55 Qadri SM, Donkor DA, Bhakta V, Eltringham-Smith LJ, Dwivedi DJ, Moore JC, Pepler L, Ivetic N, Nazi I, FoxRobichaud AE, Liaw PC, Sheffield WP: Phosphatidylserine externalization and procoagulant activation of erythrocytes induced by Pseudomonas aeruginosa virulence factor pyocyanin. J Cell Mol Med 2016;20:710720.

-56 Shan F, Yang R, Ji T, Jiao F: Vitamin C Inhibits Aggravated Eryptosis by Hydrogen Peroxide in Glucose-6Phosphated Dehydrogenase Deficiency. Cell Physiol Biochem 2016;39:1453-1462.

57 Signoretto E, Bissinger R, Castagna M, Lang F: Stimulation of Eryptosis by Combretastatin A4 Phosphate Disodium (CA4P). Cell Physiol Biochem 2016;38:969-981.

58 Signoretto E, Castagna M, Al Mamun Bhuyan A, Lang F: Stimulating Effect of Terfenadine on Erythrocyte Cell Membrane Scrambling. Cell Physiol Biochem 2016;38:1425-1434. 


\section{Cellular Physiology Cell Physiol Biochem 2017;43:431-444 \begin{tabular}{l|l|l}
\hline and Biochem 101159/000480469 & $\begin{array}{l}\text { C } 2017 \text { The Author(s). Published by S. Karger AG, Basel } \\
\text { www.karger.com/cpb }\end{array}$ \\
\hline Published online: September 19, 2017
\end{tabular} \\ Jemaà et al.: Methods in the Analysis of Eryptosis}

59 Signoretto E, Castagna M, Lang F: Stimulation of Eryptosis, the Suicidal Erythrocyte Death by Piceatannol. Cell Physiol Biochem 2016;38:2300-2310.

-60 Signoretto E, Honisch S, Briglia M, Faggio C, Castagna M, Lang F: Nocodazole Induced Suicidal Death of Human Erythrocytes. Cell Physiol Biochem 2016;38:379-392.

61 Signoretto E, Laufer SA, Lang F: Stimulating Effect of Sclareol on Suicidal Death of Human Erythrocytes. Cell Physiol Biochem 2016;39:554-564.

62 Signoretto E, Zierle J, Bissinger R, Castagna M, Bossi E, Lang F: Triggering of Suicidal Erythrocyte Death by Pazopanib. Cell Physiol Biochem 2016;38:926-938.

-63 Stockinger K, Bissinger R, Bouguerra G, Abbes S, Lang F: Enhanced Eryptosis Following Exposure to Carnosic Acid. Cell Physiol Biochem 2015;37:1779-1791.

-64 Waibel S, Bissinger R, Bouguerra G, Abbes S, Lang F: Saquinavir Induced Suicidal Death of Human Erythrocytes. Cell Physiol Biochem 2015;37:1973-1982.

65 Wesseling MC, Wagner-Britz L, Huppert H, Hanf B, Hertz L, Nguyen DB, Bernhardt I: Phosphatidylserine Exposure in Human Red Blood Cells Depending on Cell Age. Cell Physiol Biochem 2016;38:1376-1390.

66 Zierle J, Bissinger R, Bouguerra G, Abbes S, Lang F: Triggering of Suicidal Erythrocyte Death by Regorafenib. Cell Physiol Biochem 2016;38:160-172.

67 Zierle J, Bissinger R, Egler J, Lang F: Lapatinib Induced Suicidal Death of Human Erythrocytes. Cell Physiol Biochem 2015;37:2275-2287.

68 Zierle J, Bissinger R, Lang F: Inhibition by Teriflunomide of Erythrocyte Cell Membrane Scrambling Following Energy Depletion, Oxidative Stress and Ionomycin. Cell Physiol Biochem 2016;39:1877-1890.

69 Abed M, Feger M, Alzoubi K, Pakladok T, Frauenfeld L, Geiger C, Towhid ST, Lang F: Sensitization of erythrocytes to suicidal erythrocyte death following water deprivation. Kidney Blood Press Res 2013;37:567-578.

70 Tesoriere L, Attanzio A, Allegra M, Livrea MA: Dietary indicaxanthin from cactus pear (Opuntia ficus-indica L. Mill) fruit prevents eryptosis induced by oxysterols in a hypercholesterolaemia-relevant proportion and adhesion of human erythrocytes to endothelial cell layers. Br J Nutr 2015;114:368-375.

71 Tesoriere L, Attanzio A, Allegra M, Cilla A, Gentile C, Livrea MA: Oxysterol mixture in hypercholesterolemiarelevant proportion causes oxidative stress-dependent eryptosis. Cell Physiol Biochem 2014;34:10751089.

72 Voelkl J, Alzoubi K, Mamar AK, Ahmed MS, Abed M, Lang F: Stimulation of suicidal erythrocyte death by increased extracellular phosphate concentrations. Kidney Blood Press Res 2013;38:42-51.

73 Abed M, Artunc F, Alzoubi K, Honisch S, Baumann D, Foller M, Lang F: Suicidal erythrocyte death in endstage renal disease. J Mol Med (Berl) 2014;92:871-879.

74 Ahmed MS, Langer H, Abed M, Voelkl J, Lang F: The uremic toxin acrolein promotes suicidal erythrocyte death. Kidney Blood Press Res 2013;37:158-167.

75 Bissinger R, Artunc F, Qadri SM, Lang F: Reduced Erythrocyte Survival in Uremic Patients Under Hemodialysis or Peritoneal Dialysis. Kidney Blood Press Res 2016;41:966-977.

-76 Calderon-Salinas JV, Munoz-Reyes EG, Guerrero-Romero JF, Rodriguez-Moran M, Bracho-Riquelme RL, Carrera-Gracia MA, Quintanar-Escorza MA: Eryptosis and oxidative damage in type 2 diabetic mellitus patients with chronic kidney disease. Mol Cell Biochem 2011;357:171-179.

77 Polak-Jonkisz D, Purzyc L: Ca(2+) influx versus efflux during eryptosis in uremic erythrocytes. Blood Purif 2012;34:209-210; author reply 210.

78 Lang PA, Beringer O, Nicolay JP, Amon O, Kempe DS, Hermle T, Attanasio P, Akel A, Schafer R, Friedrich B, Risler T, Baur M, Olbricht CJ, Zimmerhackl LB, Zipfel PF, Wieder T, Lang F: Suicidal death of erythrocytes in recurrent hemolytic uremic syndrome. J Mol Med (Berl) 2006;84:378-388.

79 Nicolay JP, Schneider J, Niemoeller OM, Artunc F, Portero-Otin M, Haik G, Jr., Thornalley PJ, Schleicher E, Wieder T, Lang F: Stimulation of suicidal erythrocyte death by methylglyoxal. Cell Physiol Biochem 2006;18:223-232.

-80 Lang E, Gatidis S, Freise NF, Bock H, Kubitz R, Lauermann C, Orth HM, Klindt C, Schuier M, Keitel V, Reich M, Liu G, Schmidt S, Xu HC, Qadri SM, Herebian D, Pandyra AA, Mayatepek E, Gulbins E, Lang F, Haussinger D, Lang KS, Foller M, Lang PA: Conjugated bilirubin triggers anemia by inducing erythrocyte death. Hepatology 2015;61:275-284.

81 Bissinger R, Schumacher C, Qadri SM, Honisch S, Malik A, Gotz F, Kopp HG, Lang F: Enhanced eryptosis contributes to anemia in lung cancer patients. Oncotarget 2016;7:14002-14014. 


\section{Cellular Physiology Cell Physiol Biochem 2017;43:431-444 and Biochemistry Published online: September 19, 2017 \begin{tabular}{l|l} 
C 2017 The Author(s). Published by S. Karger AG, Basel \\
www.karger.com/cpb
\end{tabular} \\ Jemaà et al.: Methods in the Analysis of Eryptosis}

82 Qadri SM, Mahmud H, Lang E, Gu S, Bobbala D, Zelenak C, Jilani K, Siegfried A, Foller M, Lang F: Enhanced suicidal erythrocyte death in mice carrying a loss-of-function mutation of the adenomatous polyposis coli gene. J Cell Mol Med 2012;16:1085-1093.

83 Bissinger R, Kempe-Teufel DS, Honisch S, Qadri SM, Randrianarisoa E, Haring HU, Henes J, Lang F: Stimulated Suicidal Erythrocyte Death in Arteritis. Cell Physiol Biochem 2016;39:1068-1077.

-84 Kempe DS, Akel A, Lang PA, Hermle T, Biswas R, Muresanu J, Friedrich B, Dreischer P, Wolz C, Schumacher U, Peschel A, Gotz F, Doring G, Wieder T, Gulbins E, Lang F: Suicidal erythrocyte death in sepsis. J Mol Med (Berl) 2007;85:273-281.

-85 Foller M, Bobbala D, Koka S, Huber SM, Gulbins E, Lang F: Suicide for survival--death of infected erythrocytes as a host mechanism to survive malaria. Cell Physiol Biochem 2009;24:133-140.

-86 Lang PA, Schenck M, Nicolay JP, Becker JU, Kempe DS, Lupescu A, Koka S, Eisele K, Klarl BA, Rubben H, Schmid KW, Mann K, Hildenbrand S, Hefter H, Huber SM, Wieder T, Erhardt A, Haussinger D, Gulbins E, Lang F: Liver cell death and anemia in Wilson disease involve acid sphingomyelinase and ceramide. Nat Med 2007;13:164-170.

-87 Lupescu A, Bissinger R, Goebel T, Salker MS, Alzoubi K, Liu G, Chirigiu L, Mack AF, Qadri SM, Lang F: Enhanced suicidal erythrocyte death contributing to anemia in the elderly. Cell Physiol Biochem 2015;36:773-783.

88 Lang E, Pozdeev VI, Xu HC, Shinde PV, Behnke K, Hamdam JM, Lehnert E, Scharf RE, Lang F, Haussinger D, Lang KS, Lang PA: Storage of Erythrocytes Induces Suicidal Erythrocyte Death. Cell Physiol Biochem 2016;39:668-676.

89 Gleixner KV, Ferenc V, Peter B, Gruze A, Meyer RA, Hadzijusufovic E, Cerny-Reiterer S, Mayerhofer M, Pickl WF, Sillaber C, Valent P: Polo-like kinase 1 (Plk1) as a novel drug target in chronic myeloid leukemia: overriding imatinib resistance with the Plk1 inhibitor BI 2536. Cancer Res 2010;70:1513-1523.

90 Lang F, Abed M, Lang E, Foller M: Oxidative stress and suicidal erythrocyte death. Antioxid Redox Signal 2014;21:138-153.

91 Pandey KB, Rizvi SI: Markers of oxidative stress in erythrocytes and plasma during aging in humans. Oxid Med Cell Longev 2010;3:2-12.

-92 Ghashghaeinia M, Cluitmans JC, Akel A, Dreischer P, Toulany M, Koberle M, Skabytska Y, Saki M, Biedermann T, Duszenko M, Lang F, Wieder T, Bosman GJ: The impact of erythrocyte age on eryptosis. Br J Haematol 2012;157:606-614.

-93 O'Connor JE, Kimler BF, Morgan MC, Tempas KJ: A flow cytometric assay for intracellular nonprotein thiols using mercury orange. Cytometry 1988;9:529-532.

94 Benderitter M, Vincent-Genod L, Pouget JP, Voisin P: The cell membrane as a biosensor of oxidative stress induced by radiation exposure: a multiparameter investigation. Radiat Res 2003;159:471-483.

$\$ 95$ Tangvarasittichai S: Oxidative stress, insulin resistance, dyslipidemia and type 2 diabetes mellitus. World J Diabetes 2015;6:456-480.

\$9 Ayala A, Munoz MF, Arguelles S: Lipid peroxidation: production, metabolism, and signaling mechanisms of malondialdehyde and 4-hydroxy-2-nonenal. Oxid Med Cell Longev 2014;2014:360438.

$\$ 97$ Cheloni G, Slaveykova VI: Optimization of the C11-BODIPY(581/591) dye for the determination of lipid oxidation in Chlamydomonas reinhardtii by flow cytometry. Cytometry A 2013;83:952-961.

98 Lang E, Bissinger R, Gulbins E, Lang F: Ceramide in the regulation of eryptosis, the suicidal erythrocyte death. Apoptosis 2015;20:758-767.

-99 Lang KS, Myssina S, Brand V, Sandu C, Lang PA, Berchtold S, Huber SM, Lang F, Wieder T: Involvement of ceramide in hyperosmotic shock-induced death of erythrocytes. Cell Death Differ 2004;11:231-243.

100 Berg CP, Engels IH, Rothbart A, Lauber K, Renz A, Schlosser SF, Schulze-Osthoff K, Wesselborg S: Human mature red blood cells express caspase- 3 and caspase-8, but are devoid of mitochondrial regulators of apoptosis. Cell Death Differ 2001;8:1197-1206.

101 Kucherenko Y, Zelenak C, Eberhard M, Qadri SM, Lang F: Effect of casein kinase 1alpha activator pyrvinium pamoate on erythrocyte ion channels. Cell Physiol Biochem 2012;30:407-417.

102 Lang F, Gulbins E, Lang PA, Zappulla D, Foller M: Ceramide in suicidal death of erythrocytes. Cell Physiol Biochem 2010;26:21-28.

103 LaRocca TJ, Stivison EA, Mal-Sarkar T, Hooven TA, Hod EA, Spitalnik SL, Ratner AJ: CD59 signaling and membrane pores drive Syk-dependent erythrocyte necroptosis. Cell Death Dis 2015;6:e1773. 